\title{
IDENTIFICATION OF CHARACTERISTIC ORGANIC MOLECULES IN KERNELS OF MAIZE (Zea mays L.) HYBRID GRAIN USING INFRARED SPECTROSCOPY
}

\section{Ch. RADENOVICH ${ }^{1,}{ }^{2}$, G.V. MAKSIMOV ${ }^{3}$, E.V. TYUTYAEV ${ }^{4}$, V.V. SHUTOVA ${ }^{4}$, N. DELICH ${ }^{1}$, Z. CHAMDZHIYA', Yo. PAVLOV', Zh. JOVANOVICH ${ }^{1}$}

\begin{abstract}
${ }^{1}$ Maize Research Institute, Zemun Polje, ul. Slobodana Bajicha 1, 11185 Belgrade-Zemun, Serbia, e-mail radenovic@sbb.rs; ${ }^{2}$ Faculty of Physical Chemistry, University of Belgrade, Studentski trg 16, 11000 Belgrade, Serbia, e-mail radenovic@sbb.rs;

${ }^{3}$ M.V. Lomonosov Moscow State University, Biological Faculty, 1/12, Leninskie gory, Moscow, 119234 Russia, e-mail gmaksimov@mail.ru;

${ }^{4}$ N.P. Ogarev Mordovia State University, 68, Bol'shevistskaya ul., Saransk, Republic of Mordovia, 430005 Russia Received June 30, 2016
\end{abstract}

\section{Abstract}

Modern biophysical methods have provided a breakthrough in investigations of the status and functions of the intact plants at the molecular level. The infrared (IR) spectroscopy allows us to analyze the molecular composition and structure by recording the absorption of infrared radiation as a function of frequency of valent and deformation vibrations (wavenumber, $\mathrm{cm}^{-1}$ ) for chemical bonds. We used the IR Fourier spectroscopy method (IR spectra with Fourier Transformation,) to investigated the grain composition in maize hybrids - ZP 341, ZP 434 and ZP 505 created at Maize Research Institute (Zemun Polje, Belgrade, Serbia). The resulted spectra differed in peak number and intensity, and in oscillation frequency. Particularly, there are 20 to 23 peaks and characteristic spectral bands within the wavenumber range of 400 to $4000 \mathrm{~cm}^{-1}$. Characteristic spectral bands were analyzed for each hybrid with regard to absorption intensity in $\%$, experimentally determined wavenumber in $\mathrm{cm}^{-1}$, and published wavenumber range. A comparison of these peaks to reference IR spectra from databases revealed biogenic organic molecules: alcohols, amines, esters, alkanes, carboxylic acids, alkenes, aldehydes, ketones and esters in the studied grain hybrids. In a typical IR spectrum of maize hybrid ZP 341 there were three most distinct bands with wavenumbers of 3400, 2900 and $1000 \mathrm{~cm}^{-1}$. Four peaks $\left(3400,2950,1700\right.$ and $\left.1000 \mathrm{~cm}^{-1}\right)$ were characteristic of the ZP 434 hybrid, and eight major peaks of $3400,2900,2850,1750,1700,1450,1150$ and $1000 \mathrm{~cm}^{-1}$ were observed in ZP 505. That is, the grain charterisics in ZP 505 slightly differ from those in ZP 341 and ZP 434, whereas in ZP 341 and ZP 434 the grain structure is more similar. In general, Serbian hybrids are characterized by high quality, productivity and technological suitability. The developed methodology for IR spectra recording and analysis in grain allows to reveal the composition and structure of biogenic compounds. It is important not only for diagnosis and breeding, but also for the development of biotechnological screening methods, or the estimation of grain storage time.

Keywords: maize hybrids, grain, molecular structural characteristics, infrared spectra, spectral bands

Modern biophysical study methods have provided a significant breakthrough in the diagnostics of physical and functional condition of intact plants on the molecular level [1-9]. IR and Raman spectroscopy is a practical and effective tool in studying organic compounds, which allows to identify vibrational characteristics of molecules. Analysis of IR spectra allows to obtain important data on structural features of systems undergoing study, and the properties conditioned by said features $[2-5,10]$.

Earlier [9, 11-16] we have compared the structure of carotenoides in the grain of hybrid and inbred lines of corn (Zea mays L.) with high photosynthesis efficiency, enriched pigment composition and increased nutritious value. We have shown that the structure may be used as a molecular marker for agronomic efficiency assessment in studied forms. The IR spectroscopy method is known to allow to analyze composition and structure of molecules by register- 
ing infrared absorption depending on frequency (Wavenumber, $\mathrm{cm}^{-1}$ ) of stretching and bending vibrations of chemical bonds [3, 4].

The current study is the first to present the results of using the IR spectroscopy method for the molecular diagnostics of quality and functional characteristics in Serbian selection corn hybrids.

The goal of the study is to develop a methodology of recording and analyzing of the IR spectra of grain, which would allow to reveal the structure of biogenic compounds.

Techniques. Grain from three high yield corn hybrids ZP 341, ZP 434 and ZP 505 (originator and owner is Maize Research Institute, Zemun Polje, Belgrad, Serbia) was used for biological samples.

An IR Prestige-21 (Shimadzu Corp, Japan) spectrometer was used to record IR spectra in the $40-4000 \mathrm{~cm}^{-1}$ range with a Fourier transform (Fourier Transform Spectrometry). The samples were prepared by homogenizing the grain and embedded into tablets containing potassium bromide $(\mathrm{KBr})$. All IR spectra reflecting the dependency of infrared absorbance (abs. units) on the wavenumber were obtained in no less than 3 consequent tests with 3-5 repetitions each.

Standard methods described in more detail in classical works and by ourselves [10, 17] were employed to determine grain chemical composition.

The yielding, quality and technological suitability of hybrids for growing for grain and ensilage (selection and seed growing features, characteristics and parameters) were assessed in ecogeographic studies during 2008-2011 in the majority of areas of Serbia - Loznica (western Serbia), Sakule (South Barat), Smederevo (Podunavye), Zmaevo (South Bachka), Jarkovac (East Srem), Batosh (Middle Banat), Divosh (North Srem), Bechei (East Bachka) etc. using the standard agrotechnologies [11-13, 18].

Statistical analysis was performed using software.

Results. ZP 341, ZP 434 and ZP 505 hybrids, cultivated in Serbia, are used both in Serbia and in Russia. More than $1 \mathrm{mln}$ ha is sown in Serbia annually. The studied ZP corn hybrids are also successfully cultivated in Romania, Bosnia and Herzegovina, Croatia, Montenegro, Macedonia, Bulgaria and parts of Hungary.

The results for ZP 341, ZP 434 and ZP 505 in this study have been obtained using both common standard and modern instrumental methods.

Infrared spectra of the grain of studied hybrids. The Fourier Transform Spectroscopy that we used (Fig. 1) [4-16, 19] is known as a method of identification and feature analysis of chemical substances by their molecular IR absorbance spectra. Such a spectrum is unique for every individual compound and serves as its «molecular fingerprint», by which it can be found in respective databases. These spectra can also be employed as means of calculating the content of an element in the sample, due to absorption intensity being directly proportional to the quantity of a substance.

The spectrophotometers used for the IR spectrum bear no principal differences from such for visible and UV spectra. They do, however, have certain minor differences. These are based on IR specifics, particularly in the medium- and longwave parts of the spectrum $[1,3,20]$ and related to the nature of IR, its energy, the features of IR emitters, the usage of temperature sensors etc.

Currently, a specific type of spectrophotometers is used, based on the interferometer principle. These devices record not the spectrum itself, but an interferogram, which is later converted into a standard spectrum via computer processing. The process is called the Fourier transform, and the whole method is the Fourier Transform Spectroscopy - FTS. These instruments are the most suitable for analyzing the far ranges of the IR spectrum and possess high resolution. 


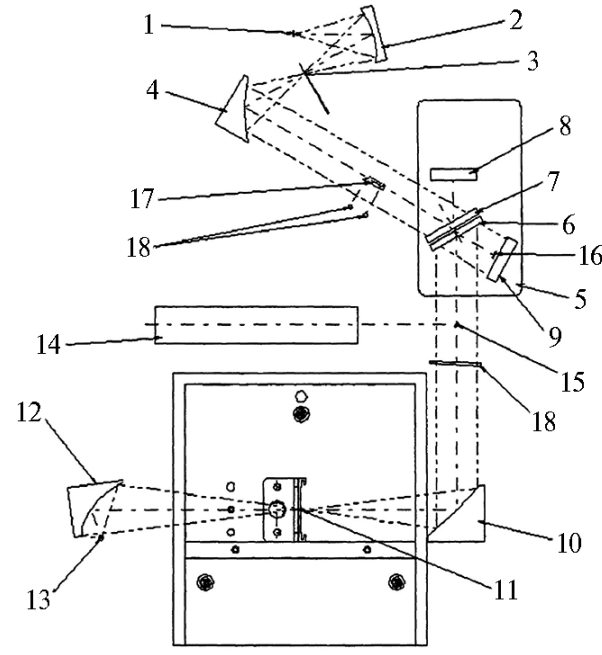

Fig. 1. Schematic diagram of the IR Prestige-21 IR-Fourier spectrometer optical system (Shimadzu Corp, Japan): 1-13 - elements of the diagram. The beam from the emitter (Position 1) is reflected by the spherical mirror (2) focused on the diaphragm (3). Going through the diaphragm, is reflected by the collimator (4), transformed into parallel, and gets into the Michelson interferometer with $30^{\circ}$ angle of incidence (5). The IR beam reflected to the interferometer is sent by the beam splitter to the rotating mirror (8) and static mirror (9). Each beam obtained that way becomes interfered by the splitter and sent to the collimator mirror (10). The parallel interfered beam projects the image of the emitter in the center of the sample compartment. The beam passes through the sample, is reflected by the collimator mirror (12) to the sensor (13), where it's recorded in the form of an interferogram.

The analysis of the obtained IR spectra (Fig. 2) has revealed approximately 20-23 spectral bands in the wavenumber range of $400 \mathrm{~cm}^{-1}$ to $4000 \mathrm{~cm}^{-1}$. The spectral bands differed in peak height, kinetics and base width. There were three to five most pronounced bands, two to three moderately pronounced and four to five bleaker bands. Several merged bands were impossible to separate, which shows an unstable condition. This condition may manifest if the vibration ranges of chemical bonds are so little for some reason, that they are practically indistinguishable. There are other explanations for this phenomenon and the system's unstable condition $[15,21]$.

The IR spectra represent the dependence of infrared absorbance on the frequency of stretching and bending vibrations of chemical bonds for multiple functional groups within biogenic organic molecules of vitamins, pigments and dietary fibers. Analysis and comparison of revealed spectral profiles first with the samples in the standard library (obtained in reference IR studies of especially clear organic substances) and then with the results of studies of organic, natural and polyatomic substances, described in literature [3-6] allowed to characterize the chemical composition and molecular structure of the grain of the three study corn hybrids with a certain level of probability. It is of note, that besides the mentioned references, the IR-spectra (about 150 thousands) are described in The American Society for Testing and Materials (ASTM) library (http://www.hellers.com/steve/resume/p101.html).

The typical ZP 341 corn hybrid IR spectrum (see Fig. 2, A) was characterized by three pronounced spectral bands with wavenumbers of 3400, 2900 and $1000 \mathrm{~cm}^{-1}$. The bands with wavenumbers of $2850,1650,1175$, and $1145 \mathrm{~cm}^{-1}$ may also be considered pronounced here. At a closer look bleak bands with wavenumbers of $3780,2300,1550,1145,1100,925,825,775,700$ and $600 \mathrm{~cm}^{-1}$ could also be seen. In the whole $4000-400 \mathrm{~cm}^{-1}$ wavenumber range an unstable condition was recorded for wavenumbers 3000,1900 and $650 \mathrm{~cm}^{-1}$.

For the ZP 434 hybrid four spectral bands stood out in the IR spectrum of the grain with wavenumbers of 3400, 2950, 1700 and $1000 \mathrm{~cm}^{-1}$ (see Fig. 2 B). Besides that, the bands with wavenumbers of 2825,1775 and $1185 \mathrm{~cm}^{-1}$ were clearly pronounced. The bands with wavenumbers of $3750,1500,1225,1100$, $975,900,800,700$ and $600 \mathrm{~cm}^{-1}$ appeared to be bleak. Wavenumbers of 3900 , $2300,1900,1400$ и $450 \mathrm{~cm}^{-1}$ [2-4] conformed to the system's unstable condition for this hybrid.

The ZP 505 hybrid, unlike the others, has eight most pronounced spec- 
tral bands with wavenumbers of 3400, 2900, 2850, 1750, 1700, 1450, 1150 and $1000 \mathrm{~cm}^{-1}$ (see Fig. 2, B). And 12 more peaks (wavenumbers of 3750, 3025, 2350, 1550, 1300, 1100, 1000, 900, 775, 700, 575 and $500 \mathrm{~cm}^{-1}$ ) were bleak. The system's unstable condition was recorded for the wavenumbers of 3850,1900 , 1800,1460 and $1430 \mathrm{~cm}^{-1}$.
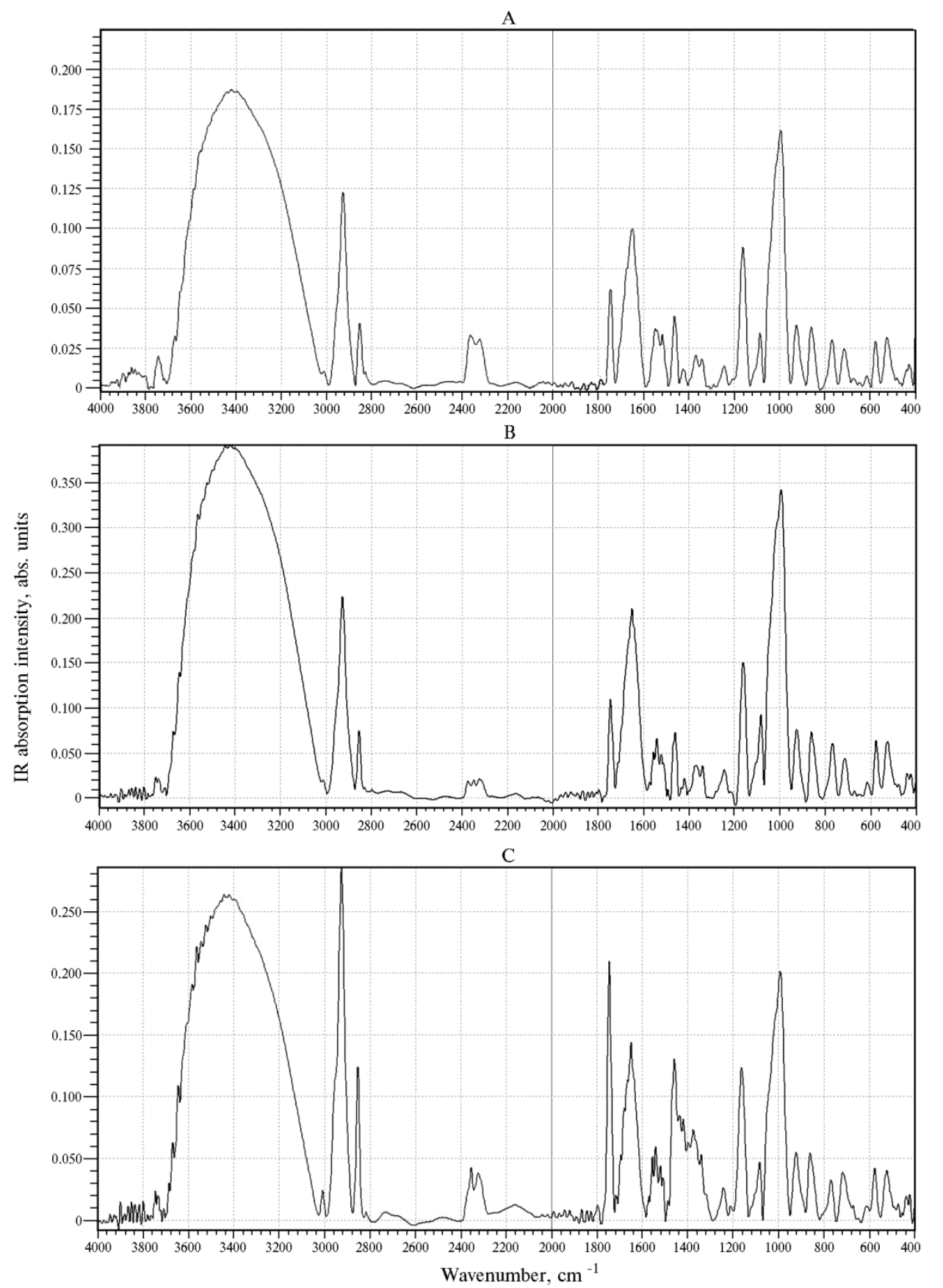

Fig. 2. The typical IR spectrum of Serbian selection corn hybrids grain (Zea mays L.) ZP 34 (A), ZP 434 (B) and ZP 505 (C) (IR Prestige-21IR-Fourier spectroscope Shimadzu Corp, Japan).

It should be noted that along with the most typical and pronounced spectral bands, obtained for corn hybrids grain, minor peaks, representing excited states in organic molecules, may also be of interest [6, 19]. 
We tried to find the answer to the pending question, if the individual class of biogenic organic molecules can be revealed by knowing the characteristics of spectral bands of respective functional groups, and whether or not there is a difference between the IR spectra of grain of ZP 341, ZP 434 and ZP 505 corn hybrids. Apparently, the data obtained in our study allow to reveal the changes in the molecular structure of the components of the grain of the hybrids.

The analysis of each IR spectrum (see Fig. 2) by five most pronounced bands allowed us to test for the presence of stretching symmetrical and asymmetrical vibrations of a $\mathrm{C}-\mathrm{H}$ group, and bending vibrations of $\mathrm{C}-\mathrm{H}$ groups. Beside that, an attempt was made to detect bending $(\mathrm{N}-\mathrm{H}, \mathrm{C}-\mathrm{N})$ and stretching $(\mathrm{C}=\mathrm{O})$ vibrations for amide bands (amide I and amide II) in molecules of proteins, peptides and $\alpha$-amino acids, stretching vibrations of $\mathrm{C}-\mathrm{H}$ bond of alkenes, stretching vibrations of $\mathrm{S}-\mathrm{O}, \mathrm{C}-\mathrm{P}, \mathrm{C}-\mathrm{S}$ bonds, bending vibrations of the $\mathrm{C}-\mathrm{H}$ bond in a molecule of terminal carbohydrates, stretching vibrations of $\mathrm{C}=\mathrm{O}$ bonds in aldehydes and ketones, $\mathrm{O}-\mathrm{H}$ bonds of secondary and tertiary alcohols (Table 1).

1. Characteristics of the main peaks of IR absorbance spectrum of the components of the grain of Serbian selection corn hybrids (Zea mays L.)

\begin{tabular}{|c|c|c|}
\hline $\begin{array}{l}\text { Band peak relative } \\
\text { to the maximum of } \\
\text { the hybrid, } \%\end{array}$ & $\begin{array}{l}\text { Wavenumber of the } \\
\text { band peak, } \mathrm{cm}^{-1}\end{array}$ & Substance class \\
\hline \multicolumn{3}{|c|}{ ZP 341 hybrid } \\
\hline 87.5 & $3400(3200-3650,3250-3500)$ & Alchohols, amines \\
\hline 70.5 & $1000(1000-1260)$ & Alcohols, ethers \\
\hline 56.0 & $2950(2840-3000,2500-3300)$ & Alkanes, carboxylic acids \\
\hline 44.0 & $1650(1620-1680,1690-1750)$ & Alkenes, aldehydes, ketones \\
\hline 38.0 & $1150(1000-1260)$ & Alcohols, ethers \\
\hline \multicolumn{3}{|c|}{ ZP 434 hybrid } \\
\hline 100 & $3410(3200-3650,3250-3500)$ & Alchohols, amines \\
\hline 88.5 & $1000(1000-1260)$ & Alcohols, ethers \\
\hline 60.5 & $2925(2840-3000,2500-3300)$ & Alkanes, carboxylic acids \\
\hline 50.0 & $1625(1620-1680,1690-1750)$ & Alkenes, aldehydes, ketones \\
\hline 39.0 & $1175(1000-1260)$ & Alcohols, ethers \\
\hline \multicolumn{3}{|c|}{ ZP 505 hybrid } \\
\hline 93.0 & $3410(3200-36503250-3500)$ & Alchohols, amines \\
\hline 100 & $2975(2840-3000,2500-3300)$ & Alkanes, carboxylic acids \\
\hline 73.0 & $1775(1735-1750,1690-1750,1710-1760)$ & Ethers, aldehydes, ketones, carboxylic acids \\
\hline 67.0 & $1000(1000-1260)$ & Alcohols, ethers \\
\hline 49.5 & $1650(1690-1750,1620-1680)$ & Aldehydes, ketones, alkenes \\
\hline
\end{tabular}

During the analysis of the IR spectra (see Fig.2, Table 1) the absorption intensity for the most pronounced spectral bands, wavenumbers, at which such peaks manifest, the data on wavenumber ranges in literature [6], absorption intensity and frequencies of stretching and bending vibrations of functional groups of biogenic molecules were taken into account. This allowed us to characterize the composition of biogenic molecules and their structural features in the grain of corn hybrids ZP 341, ZP 434 and ZP 505 [21, 23]. We identified alkanes, alkenes, amines, alchohols, ethers, carboxylic acids, aldehydes and ketones [21, 23 ] in the grain of ZP 341, ZP 434 and ZP 505 by comparing our data to the data on various substance classes in the literature $[6,20,24]$. According to the results obtained (see Table 1) we can suggest that the charcteristics of ZP 341 and ZP 434 grain are consimilar, while such of ZP 505 are different from the other two hybrids.

The quality, productivity and technological suitability of the hybrids. Table 2 represents the chemical composition of the grain of $\mathrm{ZP}$ 341, ZP 434 и ZP 505 by the primary characteristics. The data presented corresponds to the results of studies of vitamin and dietary properties of the grain, 
obtained by foreign authors $[6,8,9,16]$ and was discussed by us in detail earlier [21].

2. The results of the analysis of the chemical composition of the grain of study Serbian selection corn hybrids (Zea mays L.) (the mean of 3 years, experimental corn field of Zemun Polje Corn Institute, Belgrad, Serbia)

\begin{tabular}{l|c|c|c|c|c}
\hline \multirow{2}{*}{ Indicator } & \multicolumn{2}{c|}{ The data in literature (16) } & \multicolumn{3}{c}{ The mean of the experiment } \\
\cline { 2 - 6 } & limits & mean & ZP 341 & ZP 434 & ZP 505 \\
\hline Humidity, \% & $7-23$ & 16.0 & 11.96 & 11.56 & 11.14 \\
Starch, \% & $61-78$ & 71.7 & 70.40 & 72.04 & 73.38 \\
Proteins, \% & $6-12$ & 9.5 & 9.75 & 10.15 & 9.88 \\
Lipids (oil), \% & $1.0-5.7$ & 4.3 & 6.28 & 6.02 & 6.38 \\
Ash, \% & $1.1-3.9$ & 1.4 & 1.34 & 1.40 & 1.31 \\
\hline
\end{tabular}

ZP 341, ZP 434 and ZP 505 hybrids are characterized by significantly higher quality, and are generally meant to be grown in the European corn zone, where they have shown high productivity $[15,21]$ (Table 3 ). The genetic productivity potential of ZP 341, ZP 434 and ZP 505 was studied in Serbia at 38 geographical points in 2008, at 35 points in 2009 m, at 41 in 2010 and at 37 point in 2011. A standard growing technology with no irrigation was used.

3. The productivity of study Serbian selection corn hybrids (Zea maysL.) at a standard growing technology with no irrigation in ecogeographic studies (Serbia, 2008-2011)

\begin{tabular}{l|c|c|c|c|c|c}
\hline \multicolumn{1}{c|}{ Hybrid } & \multirow{2}{*}{2008} & \multirow{2}{*}{2009} & \multirow{2}{*}{2010} & \multirow{2}{*}{2011} & \multicolumn{2}{c}{ Mean productivity of the hybrid } \\
\cline { 6 - 7 } & & & & & ton/ha & $\%$ \\
\hline ZP 341 & 7.299 & 9.318 & 8.389 & 7.626 & 8.158 & 100.0 \\
ZP 434 & 7.432 & 9.522 & 8.393 & 7.788 & 8.284 & 101.6 \\
ZP 505 & 7.580 & 9.706 & 8.752 & 7.918 & 8.489 & 104.1 \\
$\quad \begin{array}{lllll}\text { Mean by year: } \\
\quad \text { ton/ha }\end{array}$ & & & & & \\
$\quad \%$ & 7.437 & 9.515 & 8.511 & 7.777 & 8.310 & \\
\hline
\end{tabular}

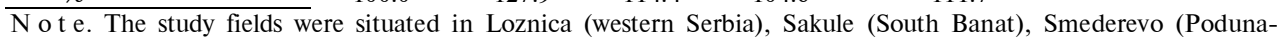
vye), Zmaevo (South Bachka), Jarkovce (East Srem), Batoshe (Middle Banat), Divoshe (North Srem), Bechee (East Bachka) etc.

It has been established that the hybrids differed only slightly in productivity. That being said, if ZP 341 is $100 \%$, ZP 434 has $1.6 \%$ higher productivity (0.126 ton/ha) and ZP 505 is $4.1 \%$ higher (0.331 ton/ha), which suggests a sufficiently close selective productivity potentials of study forms. The higher selective potential of ZP 505 can probably be explained by its longer vegetation period. The dynamics of changing of study parameters, however, were significantly different. Taking the 2008 productivity minimum as $100 \%$, we have a $4.6 \%$ (0.340 ton/ha) excess in 2011, $14.4 \%$ (1.074 ton/ha) in 2010, and $27.9 \%$ (2.078 ton/ha) in 2009. That data demonstrates the degree of influence of climate conditions on corn productivity in different years.

The main selection, seeding and technology characteristics of the hybrids are generalized in Table 4. Preliminary results of studies (see Tables 2-4) clearly prove high quality, productivity and effectiveness of biotechnological application of Serbian selection hybrids.

Therefore, that was the first recording of IR spectra of ZP 341, ZP 434 and ZP 505 hybrids grain. The spectra obtained bear characteristic bands and peaks (20 to 23 ) in the wavenumber range of 400 to $4000 \mathrm{~cm}^{-1}$. It is established, that the recorded spectral bands may be pronounced at different degrees (strong, moderate, bleak) and have different absorption intensity (\%), different kinetics and base width. Five spectral bands were tested for each of the study hybrids, which have specific characteristics (absorption intensity, \%, experimentally established wavenumber, $\mathrm{cm}^{-1}$, wavenumber range by the data in literature). Analysis of the peaks and comparing them to the known databases 
(reference IR spectra) allowed to reveal biogenic organic molecules in study hybrides grain: alcohold, amines, ethers, alkanes, carboxylic acids, alkenes, aldehydes, ketones and athers. The structural characteristics of ZP 505 grain differ slightly of such for ZP341 and ZP 434, being consimilar for the two latter. In general, the study samples of Serbian selection hybrids are characterized by high quality, productivity and technological suitability for cultivation.

4. Agronomy and morphology characteristics of Serbian selection corn hybrids (Zea maysL.) during field study

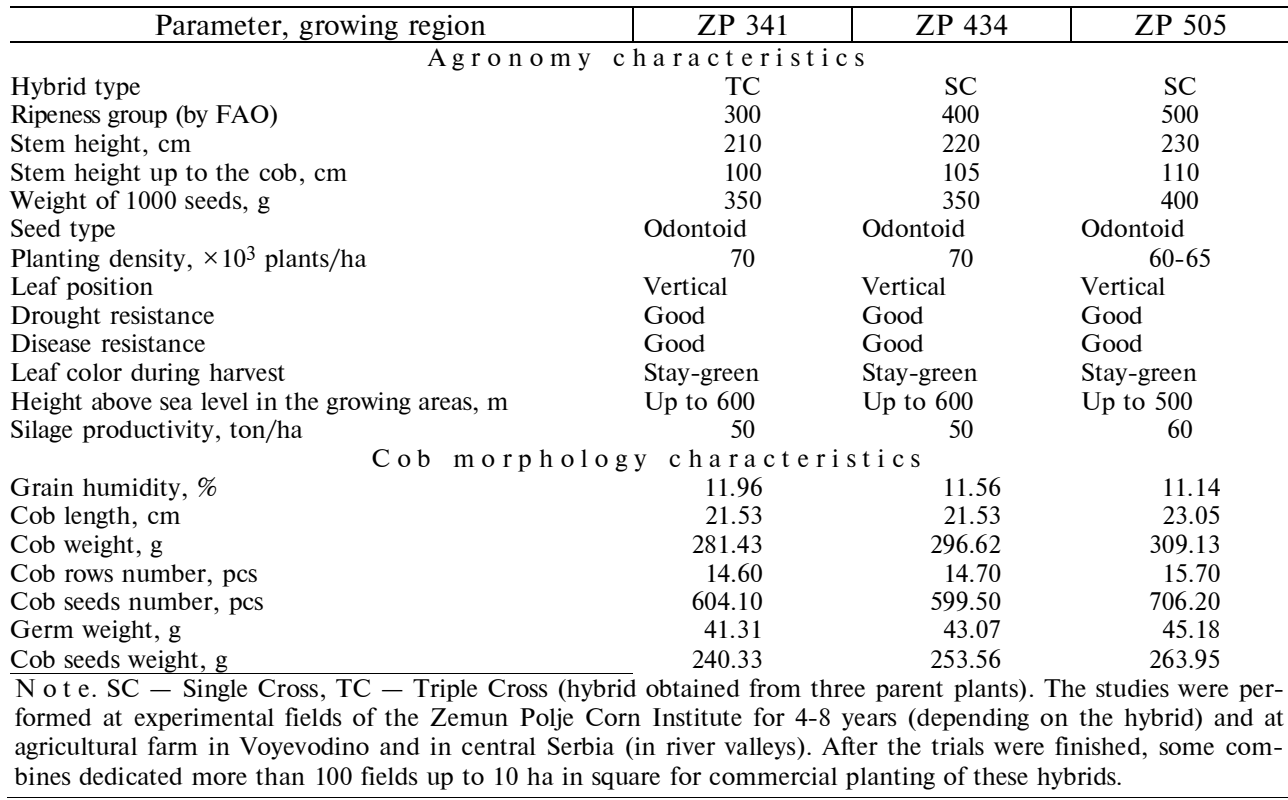

Thus, IR spectroscopy was used to study the molecular composition of grain of different hybrids for the first time, which is important not only for diagnostics and selection, but also to develop a methodology of biotechnology screening or determining grain storage time limits. The approach developed, making revealing of biogenic structures possible, allows to control changes of content or synthesis of different components of the grain and its composition at the genetic level.

\section{REFEREN C ES}

1. Ribnikar S. Infracrvena i Ramanska spektroskopija. In.: Fizičkohemijske metode. Beograd, 1985: 251-266.

2. K ri m m S., B a nd e k a r J. Vibrational spectroscopy and conformation of peptides, polypeptides and proteins. Adv. Protein Chem., 1986, 38: 181-364.

3. V a sil e v A., H ri y e $\mathrm{nk}$ o E.V., S h c hu k i n A.O. Infrared spectroscopy of organic and natural products. St. Petersburg, 2007: 1-30.

4. T a r a s e vi c h B.N. IK-spektry osnovnykh klassov organicheskikh soedinenii [IR-spectra of major classes of organic compounds]. Moscow, 2012 (in Russ.).

5. Sverdlov L.M., Kov ne r M.A., Krai nov E.P. Kolebatel'nye spektry mnogoatomnykh molekul [Vibrational spectra of polyatomic molecules]. Moscow, 1970 (in Russ.).

6. Vollhardt P.C., Schore N.E. Organic chemistry. W.H. Freeman and Company, United States, 1996.

7. Kukuruza na poroge tret'ego tysyacheletiya - Vospominaniya, rasskazy i prognozy /Pod redaktsiei Ch. Radenovicha, M. Somboratsa [Corn on the threshold of the third millennium - Memories, stories and forecasts. Ch. Radenovich, M. Somborac (eds.)]. Institut kukuruzy «Zemun Pole», Belgrad, 2000.

8. Granado F., O $1 \mathrm{medi} 11$ a B., B la n c o I. Nutritional and clinical relevance of lutein in human health. Brit. J. Nutr., 2003, 90: 487-502 (doi: 10.1079/BJN2003927).

9. Vollh ardt P.C., S c h or e N.E. Organic chemistry. W.H. Freeman and Company, USA, 1996. 
10. Corn: chemistry and technology. P.J. White, L.A. Johnson (eds.). Minnesota, USA, 2003: 71-101.

11. Radenović Č., Jeremić M., Maksimov G.V., Filipovović M., Trifunović B.V., M i š o vi ć M.M. Mogućnost korišćenja ramanske spektroskopije u proučavanju otpornosti inbred linija kukuruza prema uslovima stresa. Savremena poljoprivreda, 1994, 42(1-2): 5-19.

12. Radenović Č., Jeremić M., Maksimov G.V., Mišović M.M., Trifunović B.V. Resonance Raman spectra of carotenoids in the maize seed tissue - a new approach in studies on effect of temperatures and other environmental factors on the state of vital functions. $J$. Sci. Agric. Res., 1994, 55(4): 33-47.

13. Radenović Č., Jeremić M., Maksimov G.V., Mišović M.M., Selaković D., Trifunović B.V. Rezonantni ramanski spektri semena kukuruza i njihova primena $u$ proučavanju životnih funkcija. In: Oplemenjivanje, proizvodnja i iskorišćavanje kukuruza - 50 godina Instituta za kukuruz «Zemun Polje». Beograd, 1995: 291-296.

14. Radenović Č., Jeremić M., Maksimov G.V., Mišović M.M., Selaković D. Resonance Raman spectra of carotenoids in the maize kernel - a contribution to the evaluation of the kernels resistance to the temperature and the chemical composition of soil. Proceedings for Natural Science, Matica Srpska (Novi Sad), 1998, 95: 41-50.

15. Maksi mov G.V., R a d e novi ch N., B or i s v a Yu.E., E re m i c h M.K. Biofizi$k a, 1996,41:$ 400-406 (in Russ.).

16. Li u R.H. Whole grain phytochemicals and health. Journal of Cereal Science, 2007, 46: $207-$ 219 (doi: 10.1016/j.jcs.2007.06.010).

17. Radosavljević M., Bekrić V., Božović I., Jakovljević J. Physical and chemical properties of various corn genotypes as a criterion of technological quality. Genetika, 2000, 32(3): 319-329.

18. Vide nović Ž., S i mić M., S rdić J., D u ma novi ć Z. Long term effects of different soil tillage systems on maize (Zea mays L.) yields. Plant, Soil and Environment, 2011, 57(4): 186-192.

19. Instruction manual user system guide IRPrestige-21 (P/N 206-72010) Shimadzu Fourier transform infrared spectrophotometer. Shimadzu Corporation, Kyoto, Japan (http://www.shimadzu.com).

20. Instruction manual user system guide IRPrestige-21 (P/N 206-72010) Shimadzu Fourier transform infrared spectrophotometer, Fig. 1.8. Shimadzu Corporation, Kyoto, Japan, pp. 1-11.

21. Radenovich Ch., Maksimov G.V., Tyutyaev E.V., Shutova V.V., Delich N.S., Sechanski M.D., Popovich A.S. Selekcija i semenarstvo, 2014, XX(2): 13-31.

22. Radenović Č., Maksimov G.V., Delić S.N., Stanković J.G., Sečanski D.M., Pavlović D.M., Mitić N. Infrared spectroscopy analysis of the maize grain chemical content. Proc. $12^{\text {th }}$ International Conference on fundamental and applied aspects of physical chemistry «Physical chemistry 2014», Serbia. Belgrade, 2014. V. II: 530-533.

23. Radenović Č., Maksimov G.V., Grodzinskij M.D. Identification of organic molecules in kernels of maize inbred lines displayed with infrared spectra. Plant Physiology and Genetics (Kiev, Ukraine), 2015, 47(1/273): 15-24.

24. Corn: shemistry and technology. P.J. White, L.A. Johnson (eds.). American Association of Cereal Chemists, Minnesota, USA, 2003: 71-101. 